\title{
POLA PENGGUNAAN ANTIBIOTIKA PADA PASIEN DEWASA DENGAN DEMAM TIFOID DI RSUP SANGLAH DENPASAR TAHUN 2016-2017
}

Putu Resika Melarosa $^{1}$, Desak Ketut Ernawati ${ }^{2}$, Agung Nova Mahendra ${ }^{2}$

${ }^{1}$ Program Studi Pendidikan Dokter Fakultas Kedokteran Universitas Udayana

${ }^{2}$ Bagian Farmakologi, Fakultas Kedokteran, Universitas Udayana

E-mail: melarosa.resika@yahoo.com

\begin{abstract}
ABSTRAK
Demam tifoid atau yang dikenal dengan demam enterik merupakan penyakit infeksi sistemik yang berpotensi fatal yang disebabkan oleh bakteri Salmonella enterica typhi (S.typhy). Pada daerah endemik, sekitar $90 \%$ dari demam enterik adalah demam tifoid. Indonesia memilki insiden yang cukup tinggi dengan jumlah kasus yang terus meningkat. Diperkirakan mortalitas dari kasus demam tifoid di Indonesia antara 0,6\% sampai $2 \%$. Antibiotika merupakan terapi utama untuk penanganan pasien demam tifoid. Tujuan penelitian ini adalah untuk mengetahui pola penggunaan antibiotika pada dewasa dengan demam tifoid di RSUP Sanglah Denpasar tahun 2016-2017. Jenis penelitian yang digunakan adalah observasional dengan metode crosssectional. Pengambilan data dilakukan secara retrospektif. Sampel diambil dari rekam medis pasien dewasa dengan demam tifoid yang dirawat di RSUP Sanglah Denpasar tahun 2016-2017. Teknik pemilihan subjek menggunakan total sampling. Subjek merupakan pasien dewasa dengan demam tifoid yang dirawat di RSUP Sanglah Denpasar. Total sampel yang diperoleh sebanyak 55 pasien dewasa dengan demam tifoid. Golongan antibiotika yang digunakan di RSUP Sanglah adalah ampisilin, sefalosporin generasi ketiga, fluorokuinolon, dan azitromisin. Jenis antibiotika yang digunakan seperti ampisilin, seftriakson, sefiksim, levofloxacin, dan azitromisin. Dapat disimpulkan bahwa antibiotika yang digunakan di RSUP Sanglah Denpasar adalah jenis levofloxacin $(45,5 \%)$ dari golongan fluorokuinolon dengan rute pemberian di rumah sakit secara intravena dan diberikan selama 3-7 hari.
\end{abstract}

Kata kunci : Demam tifoid, Antibiotika, RSUP

\section{ABSTRACT}

Typhoid fever or known as enteric fever is a potentially fatal systemic infectious disease caused by Salmonella enterica typhi (S.typhy) bacteria. In endemic areas, about $90 \%$ of enteric fever is typhoid fever. Indonesia has a fairly high incidence with increasing number of cases. It is estimated mortality from cases of typhoid fever in Indonesia between $0,6 \%$ to $2 \%$. Antibiotics is the main therapy for the treatment of typhoid fever patients. The purpose of this study was to determine the pattern of antibiotic use in adults with typhoid fever at Sanglah Denpasar Hospital in 2016-2017. The type of research used is observasional with cross-sectional method. Data retrieval is done retrospectively. Samples were taken from the medical records of adult patients with typhoid fever treated at Sanglah Denpasar Hospital in 2016-2017. Subject selection techniques use total sampling. The subject is an adult patient with typhoid fever treated at Sanglah Hospital Denpasar. Total samples obtained were 55 adult patients with typhoid fever. The antibiotic classes used in Sanglah Hospital are ampicillin, third generation cephalosporin, fluoroquinolone, and azithromycin. Types of antibiotics used such as ampicillin, ceftriaxone, cefixime, levofloxacin, and azithromycin. It can be concluded that the antibiotic used at Sanglah Denpasar Hospital is kind of levofloxacin $(45,5 \%)$ from fluoroquinolone group with intravenous route of intravenous administration and given for 3-7 days.

Keywords: Typhoid fever, Antibiotics, RSUP

\section{PENDAHULUAN}

Penyakit demam tifoid atau yang dikenal dengan penyakit tifus merupakan salah satu masalah kesehatan yang terjadi di masyarakat. Pada daerah endemik, sekitar 90\% kasus dari demam enterik adalah kasus demam tifoid dan sampai saat ini demam tifoid masih menjadi topik yang sering diperbincangkan. ${ }^{1}$ Demam tifoid merupakan salah satu penyakit endemik di Indonesia yang termasuk dalam penyakit menular yang tercantum dalam Undang- undang No 6 tahun 1962 tentang wabah. Insiden penyakit ini di Bali menurut RISKESDAS pada tahun 2007 terdapat $0,9 \%$ kasus demam tifoid yang terdiagnosis. ${ }^{2}$

$$
\text { Pada dasarnya demam tifoid }
$$

merupakan penyakit infeksi akut yang mengenai saluran pencernaan dengan gejala seperti demam lebih dari tujuh hari, gangguan pada 


\section{DOA J J DORECTORY OF}

saluran cerna, dan beberapa kasus yang tergolong berat menyebabkan adanya gangguan kesadaran. ${ }^{3}$ Demam tifoid disebabkan

oleh infeksi bakteri yang bernama bakteri Salmonella typhi atau yang disingkat dengan bakteri $S$. typh. Bakteri ini merupakan genus Salmonella yang dapat masuk ke dalam tubuh manusia melalui makanan yang tercemar. Penyebarannya terjadi melalui fecal-oral.

Penggunaan obat antibiotika merupakan terapi utama pada demam tifoid karena pada dasarnya infeksi dari $S$. typhi berhubungan dengan keadaan bakteriemia. Pengobatan demam tifoid dengan menggunakan antibiotika yang empiris dan tepat sangatlah penting, karena dapat mencegah terjadinya komplikasi dan mengurangi angka kematian. ${ }^{4}$ Pemakaian antibiotika yang irasional dapat memberikan efek yang negatif seperti pembiayaan pengobatan yang meningkat, peningkatan dari adanya resistensi obat, meningkatkan toksisitas, serta meningkatkan kemungkinan efek samping dari penggunaan antibiotika. $^{5}$ Ketepatan dalam penggunaan antibiotika sangatlah penting dalam praktek medik bagi tenaga kesehatan.

Berdasarkan tingginya kasus demam tifoid dan maraknya penggunaan antibiotika sebagai pengobatan utama demam tifoid menyebabkan penelitian ini sangat penting dilakukan untuk mengetahui bagaimana pola penggunaan antibiotika pada pasien dewasa dengan demam tifoid di RSUP Sanglah Denpasar.

\section{BAHAN DAN METODE}

Penelitian ini dilakukan dengan metode cross sectional yang merupakan suatu bentuk penelitian observasional (non eksperimental). Data yang diperoleh dianalisis secara deskriptif untuk mendapatkan gambaran mengenai pola penggunaan antibiotika pada pasien dewasa dengan demam tifoid di RSUP Sanglah Denpasar periode 1 April 2016 sampai dengan 31 Maret 2017. Pengambilan data dilakukan secara retrospektif dan hanya dilakukan sekali tanpa adanya follow-up.

Sampel penelitian akan diambil dengan teknik total sampling yaitu dengan mengambil seluruh sampel dari catatan rekam medis seluruh pasien dewasa dengan demam tifoid yang dirawat di RSUP Sanglah Denpasar periode 1 April 2016- 31 Maret 2017 yang memenuhi kriteria inklusi dan eksklusi.

\section{HASIL}

Dari seluruh nomor rekam medis yang dicatat didapatkan 95 pasien dewasa dengan demam tifoid, pada periode 01 April 2016- 31
Maret 2017. Selanjutnya dipilih pasien yang memenuhi kriteria inklusi dan ekslusi, sehingga didapatkan 55 pasien dewasa dengan demam tifoid di RSUP Sanglah Denpasar yang kemudian dijadikan sampel dalam penelitian ini.

Karakteristik Umum Sampel Penelitian

Tabel 1. Distribusi sampel berdasarkan jenis kelamin

\begin{tabular}{lll}
\hline Jenis Kelamin & $\begin{array}{l}\text { Jumlah } \\
(\mathrm{n})\end{array}$ & $\begin{array}{l}\text { Persentase } \\
(\%)\end{array}$ \\
\hline Laki-laki & 36 & 65,5 \\
Perempuan & 19 & 34,5 \\
\hline Jumlah & 55 & 100
\end{tabular}

Karakteristik umum sampel penelitian terdiri dari jenis kelamin dan umur dari sampel. Berdasarkan Tabel 1 persentase laki-laki dewasa yang mengalami demam tifoid lebih banyak dibandingkan dengan perempuan yaitu sebanyak $65,5 \%$.

Tabel 2. Distribusi sampel berdasarkan umur

\begin{tabular}{lll}
\hline Umur (th) & $\begin{array}{l}\text { Jumlah } \\
(\mathrm{n})\end{array}$ & Persentase $(\%)$ \\
\hline $18-34$ & 31 & 56 \\
$35-59$ & 19 & 35 \\
$>60$ & 5 & 9 \\
\hline Total & 55 & 100 \\
\hline
\end{tabular}

Berdasarkan hasil penelitian penulis yang tercantum pada tabel 2 dibawah ini menunjukan bahwa kasus demam tifoid yang terjadi di RSUP Sanglah Denpasar paling banyak terjadi pada umur 18-34 tahun dengan persentase $56 \%$.

Tabel 3. Golongan dan Jenis Antibiotika yang digunakan

\begin{tabular}{|c|c|c|c|c|}
\hline NO & $\begin{array}{c}\text { Golongan } \\
\text { Antibiotika }\end{array}$ & $\begin{array}{c}\text { Jenis } \\
\text { Antibiotik } \\
\end{array}$ & $\begin{array}{c}\text { Frekuensi } \\
\text { (n) }\end{array}$ & $\begin{array}{c}\text { Persentase } \\
(\%)\end{array}$ \\
\hline 1. & Fluorokuinolon & Levofloxacin & 25 & 45,5 \\
\hline 2. & $\begin{array}{l}\text { Cephalosporin } \\
\text { generasi ketiga }\end{array}$ & $\begin{array}{l}\text { Ceftriaxone } \\
\text { Cefixime }\end{array}$ & $\begin{array}{c}22 \\
5\end{array}$ & $\begin{array}{c}40 \\
9\end{array}$ \\
\hline 3. & Azitromisin & Azitromisin & 2 & 3,5 \\
\hline 4. & Ampisilin & Ampisilin & 1 & 2 \\
\hline
\end{tabular}

Golongan antibiotika pada Tabel 3 yang digunakan untuk menangani pasien dewasa dengan demam tifoid di RSUP Sanglah Denpasar periode April 2016- Maret 2017 adalah antibiotika golongan fluorokuinolon dan cephalosporin generasi ketiga dengan 
antibiotika yang digunakan adalah levofloxacin sebanyak 45,5\%.

Tabel 4. Rute dan Durasi Pemberian Antibiotika

\begin{tabular}{llcccccc}
\hline \multirow{2}{*}{ Antibiotik } & \multicolumn{3}{c}{ Rute } & \multicolumn{3}{c}{ Durasi } \\
& & \multicolumn{2}{c}{ Pemberian } & \multicolumn{2}{c}{} \\
\cline { 2 - 8 } & & I0 & IV & Kontrol & $3-7$ & $8-14$ & $>14$ \\
(n) & (n) & & hari & hari & hari \\
\hline \multirow{6}{*}{ Ampisilin } & 1 & 0 & 0 & 1 & 0 & 0 \\
& Cephalosporin & 5 & 22 & 5 & 13 & 7 & 2 \\
& Generasi Ketiga & & & & & & \\
& Fluorokuinolon & 1 & 24 & 3 & 13 & 9 & 0 \\
& Azitromisin & 2 & 0 & 0 & 1 & 0 & 1 \\
\hline Total & & 9 & 46 & 8 & 28 & 16 & 3 \\
\hline
\end{tabular}

Pada tabel 4 menunjukkan rute dan durasi pemberian antibiotika pada pasien dewasa dengan demam tifoid yang berada di RSUP Sanglah Denpasar. Sebagian besar kasus demam tifoid yang dirawat di RSUP Sanglah Denpasar diberikan jenis antibiotika levofloxacin secara intravena yaitu sebanyak 24 pasien dengan durasi terbanyak diberikan selama 3-7 hari.

\section{PEMBAHASAN}

Dalam penelitian ini, 55 sampel berjenis kelamin laki-laki dan perempuan telah diambil. Berdasarkan hasil yang telah didapatkan, pasien dewasa dengan demam tifoid lebih banyak dialami oleh pasien berjenis kelamin laki-laki dibandingkan perempuan karena dikaitkan dengan kebiasaan hidup dari laki-laki yang berisiko lebih tinggi terkena paparan untuk terkena demam tifoid dibandingkan perempuan. ${ }^{6}$ Usia pasien yang terkena demam tifoid paling banyak pada rentang 18 sampai dengan 34 tahun. Usia tersebut berkaitan dengan buruknya sanitasi yang terdapat pada masyarakat. Serupa dengan penelitian yang dilakukan di RSUP Sanglah Denpasar, penelitian dari luar juga melaporkan kematian tertinggi kedua terbanyak terjadi pada pasien yang berusia 18-34 yaitu sebanyak $26 \%$. $^{7}$

Menurut hasil penelitian ini pada Tabel 3 golongan antibiotika yang digunakan untuk menangani pasien dewasa dengan demam tifoid di RSUP Sanglah Denpasar periode April 2016Maret 2017 adalah antibiotika golongan cephalosporin generasi ketiga dan golongan fluorokuinolon. Tingginya MDR atau Multi Drugs Resistence menyebabkan perawatan demam tifoid dengan menggunakan antibiotika pada lini kedua seperti fluorokuinolon atau cephalosporin sangat disarankan. ${ }^{8}$ Pembersihan waktu demam pada pasien yang diberikan golongan cephalosporin dan fluorokuinolon menjadikan tolak ukur yang setara atau lebih baik dibandingkan dengan semua antimikroba lainnya. ${ }^{9}$ Obat tersebut menjadi pilihan karena saat ini golongan kloramfenikol yang dinyatakan sebagai obat lini pertama tidak lagi digunakan sebagai obat lini pertama karena berkaitan erat dengan tingginya tingkat kekambuhan dan efek samping yang ditimbulkan. Adapun beberapa efek samping yang dapat ditimbulkan dari penggunaan kloramfenikol pada dewasa maupun anak yaitu supresi sumsum tulang, grey baby syndrome, neuritis optik pada anak, pertumbuhan candida di saluran cerna, dan timbulnya ruam. ${ }^{10,15}$

Golongan cephalosporin seperti ceftriaxone dipilih karena lebih cepat dalam menurunkan suhu tubuh, jangka waktu administrasi yang pendek, bisa digunakan sebagai dosis tunggal, dan cukup aman penggunaannya pada dewasa maupun digunakan pada anak-anak. ${ }^{11}$ Namun dari hasil penelitian yang dilakukan sampai saat ini golongan fluorokuinolon seperti levofloxacin dianggap optimal untuk pengobatan demam tifoid pada orang dewasa termasuk di RSUP Sanglah Denpasar. Penggunaan levofloxacin dipilih karena levofloxacin merupakan antibiotika golongan fluorokuinolon grup III yang memiliki sprektum luas yang efektif melawan bakteri gram negatif dan gram positif. Seperti golongan fluorokuinolon lainnya, levofloxacin juga digunakan untuk menangani bakteri S.typhy yang resisten terhadap lini pertama. $^{12}$ Penggunaan antibiotika golongan fluoroquinolon dipilih karena harganya yang relatif murah, dapat ditoleransi dengan baik, dan lebih cepat serta efektif daripada obat lini pertama sebelumnya. Selain itu golongan fluorokuinolon juga mencapai penetrasi jaringan yang sangat baik dan dapat membunuh bakteri S. typhi di tahap stasioner intraselularnya pada monosit/makrofag dan mencapai tingkat aktif yang lebih tinggi di kantung empedu dibanding obat lain. ${ }^{1}$

Levofloxacin merupakan jenis antibiotika yang memberikan pembersihan demam yang lebih cepat dibandingkan dengan ciprofloxacin yang berasal dari golongan yang sama dan levofloxacin juga memberikan lebih sedikit reaksi buruk. ${ }^{13}$ Penggunaan levofloxacin secara intravena juga lebih sedikit menimbulkan ruam pada kulit yang diinjeksikan. ${ }^{14}$

Berdasarkan tabel 4 rute pemberian antibiotika levofloxacin yang digunakan dalam penelitian ini paling banyak secara intravena. Pemberian antibiotika secara peroral seharusnya menjadi pilihan pertama untuk terapi infeksi. ${ }^{15}$ Namun pada pasien yang mengalami kehilangan nafsu makan, sembelit, ataupun diare pemberian secara oral tidak akan memberikan efek yang optimal, sehingga pada infeksi yang sedang 


\section{$\square \cap \wedge \quad \begin{aligned} & \text { DIRECTORY OF } \\ & \text { OPENACCES } \\ & \text { JOURNALS }\end{aligned}$}

hingga berat penggunaan antibiotika secara intravena dapat dipertimbangkan. ${ }^{16,17}$

Pasien dewasa dengan demam tifoid idealnya akan mengalami perbaikan klinis dalam 3-7 hari. ${ }^{16}$ Namun menurut guideline penangan demam tifoid durasi atau lama pemberiaan antibiotika untuk menangani demam tifoid rata-rata selama 5-14 hari tergatung dari jenis antibiotika yang digunakan. ${ }^{17}$ Dalam penelitian ini, durasi pemberian antibiotika levofloxacin diberikan paling banyak selama 3-7 hari. Sedangkan menurut Permenkes lama pemberian terapi antibiotika harus berdasarkan pada data mikrobiologis, kondisi pasien, dan data penunjang lainnya. ${ }^{15}$ Durasi penggunaan antibiotika untuk pasien demam tifoid di RSUP Sanglah Denpasar memang tidak sama untuk setiap golongan antibiotika. Selain itu terdapat juga durasi pemberian antibiotika yang melebihi 14 hari. Pemberian yang melebihi dari 14 hari tersebut mungkin disebabkan karena adanya kesalahan dalam durasi pemberian antibiotika ataupun kesalahan dalam penulisan pada rekam medis. Hal ini belum dapat dipastikan dengan jelas karena pengambilan data yang hanya menggunakan data sekunder sehingga informasi yang didapatkan terbatas. Informasi yang tidak lengkap dari lamanya pemberian antibiotika menjadikan kendala dalam proses pengumpulan data. Sebagian besar data rekam medis tidak mencantumkan durasi pemberian setelah pasien dipulangkan, sehingga peneliti hanya dapat mencatat durasi pemberian antibiotika selama pasien berada dirumah sakit yang diambil berdasarkan lamanya rawat inap. Banyaknya informasi yang tidak dicantumkan setelah pasien keluar dari rumah sakit dan tidak adanya follow up menyebabkan hasil penelitian tentang durasi penggunaan antibiotika dalam penelitian ini masih belum akurat.

\section{SIMPULAN}

Dari hasil penelitian yang telah dilakukan, penderita demam tifoid pada dewasa paling sering terjadi pada jenis kelamin laki-laki dibandingkan perempuan, terbanyak pada usia 18 sampai 34 tahun dan jenis antibiotika yang paling sering digunakan adalah jenis levofloxacin dari golongan fluorokuinolon dengan pemberian terbanyak secara intravena selama 3-7 hari.

SARAN

Diperlukan penelitian yang lebih lanjut untuk mengetahui pola kuman yang dapat mempengaruhi dalam penggunaan antibiotika.

\section{DAFTAR PUSTAKA}

1. Nelwan, R. Tata Laksana Terkini Demam Tifoid. Continuing Medical Education: 2012 ;39(4): 247-250.
2. Putra, R., Suega, K., Bagus, A. Pedoman Diagnosis dan Terapi Ilmu Penyakit Dalam. Bagian/SMF Ilmu Penyakit Dalam Fakultas Kedokteran Universitas Udayana / RSUP Sanglah: 2013; 1: 739-751.

3. Akhsin, Z. Parasitologi. 1. Yogyakarta: Nuha Medika. 2010.

4. Sidabutar, S., Satari, H.I. Pilihan terapi empiris demam tifoid pada anak: Kloramfenikol atau Ceftriaxone?. Sari Pediatri :2010; 11(6) : 205-210

5. Widiastuti, R. "Pola Penggunaan Antibiotika pada Pasien Dewasa di Instalasi Rawat Inap di RSUP Dr Soeradji Tirtonegoro Klaten Periode JanuariDesember 2010". Surakarta. Universitas Sebelas Maret : 2011

6. Ikram, S., Shagufta H.,Aliya A. Evaluation of the Current Trends in the Antimicrobial Susceptibility Patterns of Typhoid Salmonellae. P J M H S : 2016 ;10(1) :307312.

7. Dewan, A. M., Corner, R., Hashizume, M., Ongee, E. T. Typhoid Fever and Its Association with Environmental Factors in the Dhaka Metropolitan Area of Bangladesh: A Spatial and Time-Series Approach. PLoS Negl Trop Dis : 2013 ; 7(1) : 1-14

8. Bhutta, Z. A. Typhoid fever: current concepts. Infect Dis Clin Pract : 2006 ; 14: 266-72.

9. Thompson, C.N., Abhilasha, K., Sabina D. et al. Treatment Response in Enteric Fever in an Era of Increasing Antimicrobial Resistance: An Individual Patient Data Analysis of 2092 Participants Enrolled into 4 Randomized, Controlled Trials in Nepal. CID 2017: 2017; 64(1) :1522-1531

10. Upadhyay R., Milind Y.N., Muruganathan. dkk. API Recommendations for the Management of Typhoid Fever. Journal of The Association of Physicians of India : $2015 ; 63$ : 77-96.

11. Anggraini, Anggita, B., Cicih, Qurrotul, S. The use of antibiotics in hospitalized adult typhoid patients in an Indonesian hospital. Health Science Indones : 2014 ; 1:40-43.

12. Usman, M., Muhammad A., Muhammad I.K. dkk. Comparative Pharmacokinetics of Levofloxacin in Healthy Volunteers and in Patients Suffering from Typhoid Fever. Iranian Journal of Pharmaceutical Research : 2013 ;12 (1): 147-154.

13. Nelwan, R., Khie C.L., Suharyo H. dkk. A Single Blind Comparative Randomized Non-Inferior Multicenter Study for Efficacy and Safety of Levofloxacin versus Ciprofloxacin in the Treatment of 
Uncomplicated Typhoid Fever. Scientific Reseach : 2013;3:122-127.

14. Alatas, S.A., Nicholas, W., Pevita, K., Ahmadun H., dkk. Intravenous administration of ciprofloxacin alongside levofloxacin in patients with complicated typhoid fever. African Journal of Medicine and Surgery : $2016 ; 3$ (5):079-084.

15. Permenkes Indonesia. Pedoman Umum Penggunaan Antibiotika. Jakarta: Peraturan Menteri Kesehatan Republik Indonesia. 2011.
16. Butler, T. Treatment of typhoid fever in the 21st century: promises and Shortcomings. Clin Microbiol Infect : 2011 ; 17: 959-963.

17. WHO. Guidelines fot the Diagnosis, Management, and Prevention of Typhoid Fever [Diakses pada tanggal 27 Januari 2017].

Diunduh dari:http://www.who.int/rpc/TFGuideWHO .pdf2010. 